\title{
Peer Supports and Problem Solving Skills of Nursing and Midwifery Students*
}

\author{
Hemşirelik ve Ebelik Öğrencilerinin Akran Destekleri ve \\ Problem Çözme Becerileri*
}

\author{
Nurhan DOĞAN
}

\begin{abstract}
The study was conducted to determine the problem solving skills with peer support of nursing and midwifery students. This descriptive and cross-sectional study was conducted with a total of 305 students. The data were collected using student information form, Problem Solving Inventory and Peer Cooperation Scale. Students' peer support and problem-solving skills are moderate. 1st classes in the nursing department, 2nd classes in the midwifery department, those who choose the profession because they feel close to themselves in both departments and those who are satisfied with their department, those who have authoritarian families in the nursing department and, those who have democratic and extremely relevant families in the midwifery department of students peer support scores are high. Men and 3rd classes in the nursing department, , 1st and 2nd classes in the midwifery department, those who chose their department for their family request in both departments and are not satisfied with their department, those who have authoritarian families in the nursing departmen, those who have irrelevant families in the midwifery department of students problem-solving scores are high. While there was no significant relationship between the nursing student's problem solving and peer support total scores, a negative correlation was found between the midwifery students' problem solving and peer support total scores. It was determined that the peer support and problem solving skills of the students were at a moderate level, the problem solving skills of the nursing students and the peer support of the midwifery students were higher. It was determined that the department, class, satisfaction with the department, reason for department preference and the family structure affected the peer support and problem solving skills.
\end{abstract}

Keywords: Peer support, Problem solving, Midwifery, Nursing, Student

ÖZ

Çalışma, hemşirelik ve ebelik öğrencilerinin akran desteği ile problem çözme becerilerinin belirlenmesi amacıyla yapılmıştır. Tanımlayıcı ve kesitsel türdeki bu çalışma toplam 305 öğrenci ile gerçekleştirilmiştir. Veriler öğrenci bilgi formu, Akran Destek Ölçeği ve Problem Çözme Envanteri kullanılarak toplanmıştır. Öğrencilerin akran desteği ve problem çözme becerileri orta düzeydedir. Hemşirelik bölümünde 1. sınıf, ebelik bölümünde 2. sınıfların, her iki bölümde mesleği kendine yakın hissettiği için tercih edenlerin ve bölümünden memnun olanların, hemşirelik bölümünde otoriter, ebelik bölümünde ise demokratik ve aşırı ilgili aileye sahip olanların akran desteği puanları yüksektir. Hemşirelik bölümünde erkeklerin, 3. sınıfların, ebelik bölümünde ise 1. ve 2. sınıfların, her iki bölümde ailesi isteği için bölümünü seçen ve bölümünden memnun olmayanların, hemşirelik bölümünde otoriter, ebelik bölümünde ise ilgisiz aileye sahip öğrencilerin problem çözme puanları yüksektir. Hemşirelik öğrencilerinin problem çözme ile akran desteği toplam puanları arasında anlamlı bir ilişki bulunmazken, ebelik öğrencilerinin problem çözme ile akran desteği toplam puanları arasında negatif korelasyon bulunmuştur. Öğrencilerin akran desteği ve problem çözme becerilerinin orta düzeyde olduğu, hemşirelik bölümü öğrencilerinin problem çözme becerilerinin, ebelik öğrencilerinin ise akran desteklerinin daha yüksek olduğu belirlenmiştir. Bölüm, öğrenim görülen sınıf, bölümden memnuniyet, bölüm tercih sebebi ve aile yapısının akran desteği ve problem çözme becerisini etkilediği saptanmıştır.

Anahtar Sözcükler: Akran desteği, Problem çözme, Ebelik, Hemşirelik, Öğrenci

Doğan N. (2021). Peer supports and problem solving skills of nursing and midwifery students. Journal of Higher Education and Science/Yükseköğretim ve Bilim Dergisi, 11(1), 150-161. https://doi.org/10.5961/jhes.2021.437

*This paper was presented at 5th International and 9th National Midwifery Student Congress (03-05 May 2018), Amasya, Turkey as oral presentation.

*Bu bildiri, 5. Uluslararası ve 9. Ulusal Ebelik Öğrenci Kongresi'nde (03-05 Mayıs 2018), Amasya, Türkiye'de sözlü bildiri olarak sunulmuştur.

Nurhan DOĞAN (®)

ORCID ID: 0000-0002-6713-6581

Amasya University Health Sciences Faculty, Department of Nursing, Amasya, Turkey

Amasya Üniversitesi Sağlık Bilimleri Fakültesi, Hemşirelik Bölümü, Amasya, Turkey

nurhan_dogan38@ hotmail.com

Received/Geliş Tarihi : 02.03.2020

Accepted/Kabul Tarihi: 18.04.2021 


\section{INTRODUCTION}

People want to be supported by family, friends, teachers or other people in all their happy or troubled moments. Being in the same age, gender, university or class are factors that make it easier for individuals to become friends. It is inevitable for individuals to share and cooperate with their peers in every period of life. The fact that peer support in education has increased academic achievement and satisfaction with the learning environment has led universities to tend towards peer-supported learning. This situation has also brought peer support to the agenda in nursing and midwifery education (Çırpan \& Çınar, 2013; Ünver, \& Akbayrak, 2013). Peer support for nursing and midwifery students; Increasing self-confidence, effective communication and interaction, taking important roles in teamwork can provide academic and professional development (Atasoy, \& Doğu, 2017; Fışkın \& Doğan, 2020; Yava, \& Çiçek, 2016). Nursing and midwifery students should be equipped with theoretical knowledge in order to be able to step into as a professional profession after completing their education, researcher, leader, advocate, who want to improve themself, interpersonal relationships must have good, assertiveness, empathic skills (Çelik, Karadağ, \& Hisar 2011; Hisar, Karadağ, \& Kan, 2010). It is important to enable students to communicate with many students from their departments during the university years, to increase communication and interaction among students, to promote teamwork and peer support within university resources (Francis, 2013). Belonging to a peer group; it increases problem solving, observing how other people cope with problems, questioning where they are located in society, and evaluating the behavior of others (Karantzas et al., 2013). Nurses and midwives are faced with various problems related to patient care, human relations, teamwork and management in the clinic every day, and they are expected to solve these problems effectively. Therefore, problem solving is an important skill that nurses and midwives should have, and this skill should be gained in the learning-teaching process. For this purpose, problem solving skills are included in the learning outcomes of nursing and midwifery departments (Karadağ, Alpaslan, Yıldırım, \& Pekin, 2018; Yıldırım, \& Özkahraman, 2011). The development of professionalism of future healthcare professional candidate students, the support of peers in the completion of their personalities and problem solving behaviors are also important in terms of providing services in the future (Carey, Kent, \& Latour, 2018; Ghadirian, Salsali, \& Cheraghi, 2014). Therefore, the identification of factors affecting the students' professional development and the attempt must be made to them. The study was conducted to determine the problem solving skills with peer support of nursing and midwifery students.

\section{METHODS}

\section{Study Design and Sampling}

This is a descriptive and cross-sectional example of a quantitative study. The population of the study consisted of 344 students, 257 nursing (85 male, 172 female) and 87 (female) midwifery departments of a university. All classes in the midwifery and nursing department were included in the study. The sample consisted of 219 students from nursing department, 86 students from midwifery department and 305 students. 88.66 $\%$ of the universe has been reached. 39 students who did not complete the research data, did not continue their education during the study and did not volunteer to participate in the study were not included in the study. Purposive, convenience sampling was used for re-cruitment. The study, it was made with nursing and midwifery students of a universitys in 20172018 academic year.

\section{Instruments}

\section{1) Information Form}

The form prepared by the researcher (Çalışkan \& Çınar, 2012; Hisar et al., 2010; Yüksel 2015) consists of 16 questions. It consists of 12 socio-demographic questions (age, gender, marital status, graduated school, education level, number of siblings, mother education, father education, family structure, income status, friend group, place of residence) and 4 questions about educational characteristics (class, department, department satisfaction, reason for department preference).

\section{2) Peer Cooperation Scale (PCS)}

The Turkish validity and reliability of the scale, which was developed by Kuo in 2007 (Kuo, 2007), was made by Çalışkan and Çınar in 2010 (Çalışkan \& Çınar, 2010). Scale; It is composed of 3 sub-dimensions and 17 items, 4 types of likert, physical aid, academic aid and emotional aid. Scale sub-dimension items; Physical Aid subdimension items 1, 2, 3, 4, 5, 6, 7, 12, 13 (Score interval 9-36), Academic Assistance subdimension items 8, 9, 10, 17 (Score interval 4-16), Emotional Assistance Sub-dimension items 11, 14, 15, 16 (Score interval 4-16) are evaluated and scored. The scale is scored between 17-68. As the score of scale increases, the perceived friend support increases, and the lower the score, the lower the perceived friend support. Çalışkan and Çınar (2010) cronbach's alpha was 0.95. The PCS in this study was cronbach alpha 0.849 .

\section{3) Problem Solving Inventory (PSI)}

The inventory was developed by Heppner and Petersen in 1982. Turkish validity and reliability of the inventory was made by Şahin et al. (Heppner \& Petersen, 1982; Şahin, Şahin, \& Heppner, 1993). The 6-point Likert type inventory consists of three sub-dimensions and 35 items. Scale sub-dimension items; Problem solving confidence subdimension items 5, $10,11,12,19,23,24,27,33,34,35$; Approach-avoidance subdimension items $1,2,4,6,7,8,13,15,16,17,18,20,21,28$, 30, 31; Personal control sub-dimension items 13, 14, 25, 26, 27, 32 are evaluated and scored. The three items are excluded from the scoring and score 32-192 from the inventory. The low score obtained from the inventory shows that the individual sees himself / herself competent in problem solving (Heppner \& Petersen, 1982). Şahin, Şahin, \& Heppner, 1993 cronbach's alpha was 0.80 . The PSI in this study was cronbach alpha 0.821 .

\section{Application of the Study}

The data were collected through face-to-face interviews with 


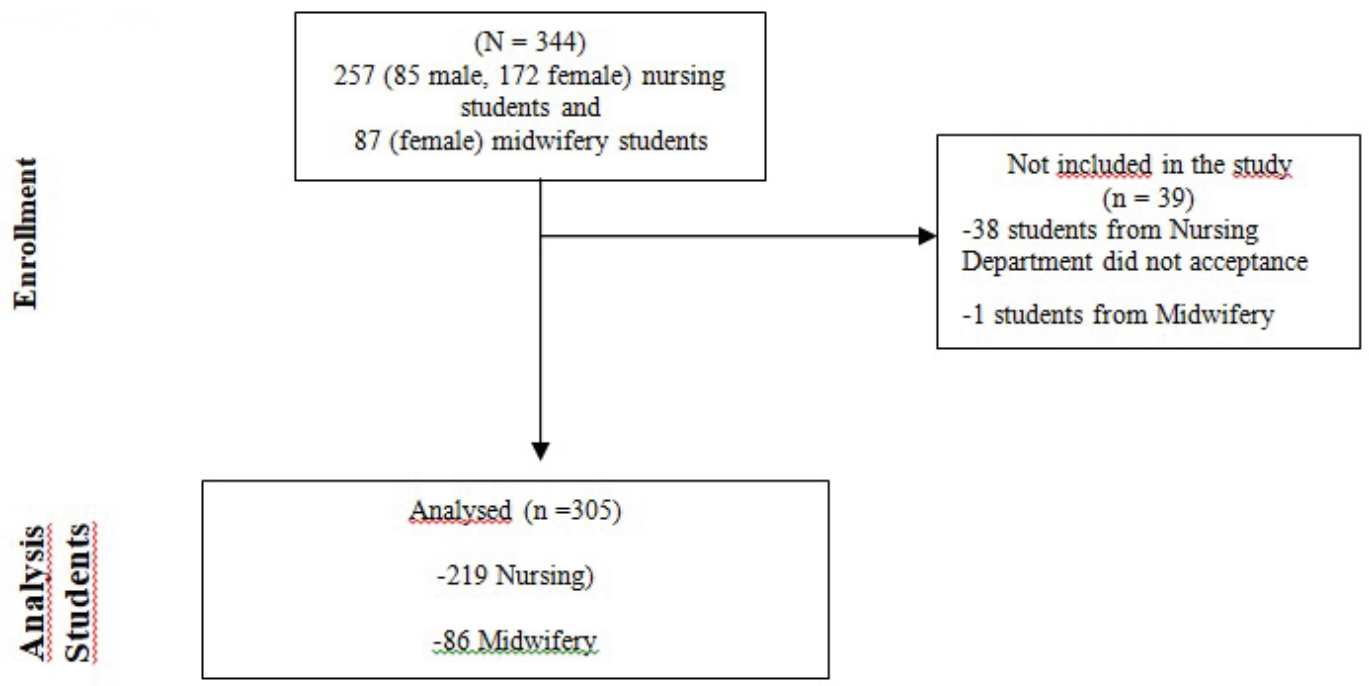

Figure 1: Study flow chart.

the students of health sciences faculty, nursing and midwifery department. Students who volunteered to participate in the research; student information form, Peer Support Scale (PCS) and Problem Solving Inventory (PSI) were applied in classroom environment. The data were collected in the spring semester of the 2017-2018 academic year. The process of answering the information form and scales was completed within an average of 20-25 minutes.

\section{Ethical Considerations}

Before starting the study, written permission was obtained from the Ethics Committee of Social and Humanities (30.01.201802) and the university. The purpose of the study was explained to the students, and their written and verbal consent was obtained.

\section{Data Analysis}

The data of the study were evaluated using in the computer. Whether the data were suitable for normal distribution was evaluated. In this direction, appropriate tests were used to evaluate the research data. In order to examine whether the two samples came from the same distribution, the Mann Whitney u test, which is a non-parametric test, was used. Ordered one-way analysis of variance, nonparametric KruskalWallis test was applied to test the equality of population medians between independent groups. Spearman test, which is a non-parametric test, was used to determine the dependency, that is, the correlation measure, between the two variables. $p$ $<.05$ value was used as a criterion for significance.

\section{RESULTS}

\section{Demographics information}

The mean age of the students was $20.36 \pm 2.14$ in the midwifery department and $20.54 \pm 2.00$ in the nursing department. It was found that the students showed similarities in terms of demographic characteristics except the satisfaction level of the department, father's education level, the place of residence and the reasons for choosing the department ( $p>.05$, Table 1).

\section{Peer Cooperation Scale}

Table 2 shows the scores of the students from PCS and the difference between them. The mean subscale scores of PCS ranged between 4-36, and the mean PCS total score was 44.35 \pm 12.17 for nursing students and $50.38 \pm 10.03$ for midwifery students, and the difference was significant $(p<.05)$. When the scores of the nursing and midwifery students in the subdimension and total of PCS were examined, a significant difference was found between the nursing and midwifery students between all sub-dimensions and total scores of PCS. $(p<.05)$. The PCS scores of the students are at moderate level. When both department were compared, mean PCS scores were higher in midwifery students $(p<.001)$.

PCS subscale and total score are significantly higher in nursing first class $(p<.05)$. In the midwifery students, emotional and academic sub-dimension and total scores of PCS are higher in the second grades, and the difference in academic assistance sub-dimension was found to be significant. $(p<.05$, Table 3$)$.

Nursing students who are satisfied with the department have higher PCS total and all sub-dimension scores $(p<.05)$. In midwifery students, it was found that the students who were satisfied with the department had higher scores than the total scores and all sub-dimensions of PCS, and only the difference was significant for the PCS subscale $(p<.05)$.

When PCS was examined according to family structure, it was found that students with authoritarian family structure had higher scores than PCS total and all sub-dimensions and the difference was significant for the PCS academic sub-dimension $(p<.05)$. Considering the reasons for choosing the department; It was found that the students who preferred nursing because they felt close to occupation had higher scores than PCS total score and all sub-dimensions and it was found that the 
Table 1: Descriptive Characteristics of Students

\begin{tabular}{|c|c|c|c|c|}
\hline \multirow[t]{3}{*}{ Descriptive Characteristics } & \multicolumn{4}{|c|}{ Groups } \\
\hline & \multicolumn{2}{|c|}{ Nursing Students ( $n=219$ ) } & \multicolumn{2}{|c|}{ Midwifery Students $(n=86)$} \\
\hline & $\mathbf{n}$ & $\%$ & $n$ & $\%$ \\
\hline Age $(\bar{x} \pm$ SD) & \multicolumn{2}{|c|}{$20.54 \pm 2.00$} & \multicolumn{2}{|c|}{$20.36 \pm 2.14$} \\
\hline $\begin{array}{l}\text { Gender } \\
\text { Female } \\
\text { Male }\end{array}$ & $\begin{array}{r}171 \\
48\end{array}$ & $\begin{array}{l}78.1 \\
21.9\end{array}$ & $\begin{array}{r}86 \\
-\end{array}$ & $\begin{array}{c}100 \\
-\end{array}$ \\
\hline $\begin{array}{l}\text { Graduation } \\
\text { Normal High School } \\
\text { Anatolian/Science High School } \\
\text { Vocational School of Health } \\
\text { Associate Degree } \\
\text { Bachelor's }\end{array}$ & $\begin{array}{r}20 \\
134 \\
54 \\
5 \\
6\end{array}$ & $\begin{array}{r}9.1 \\
61.3 \\
24.7 \\
2.2 \\
2.7\end{array}$ & $\begin{array}{r}15 \\
49 \\
21 \\
- \\
1\end{array}$ & $\begin{array}{c}17.4 \\
57.0 \\
24.4 \\
- \\
1.2\end{array}$ \\
\hline$p$ & \multicolumn{4}{|c|}{.104} \\
\hline $\begin{array}{l}\text { Class } \\
\qquad \begin{array}{l}\text { 1st class } \\
\text { 2nd class } \\
\text { 3rd class } \\
\text { 4th class }\end{array}\end{array}$ & $\begin{array}{l}60 \\
55 \\
50 \\
54\end{array}$ & $\begin{array}{l}27.4 \\
25.1 \\
22.8 \\
24.7\end{array}$ & $\begin{array}{l}29 \\
20 \\
19 \\
18\end{array}$ & $\begin{array}{l}33.7 \\
23.3 \\
22.1 \\
20.9\end{array}$ \\
\hline$p$ & \multicolumn{4}{|r|}{.310} \\
\hline $\begin{array}{l}\text { Satisfaction From Department } \\
\text { Not satisfied } \\
\text { Partially satisfied } \\
\text { Satisfied }\end{array}$ & $\begin{array}{l}22 \\
98 \\
99\end{array}$ & $\begin{array}{l}10.1 \\
44.7 \\
45.2\end{array}$ & $\begin{array}{r}5 \\
20 \\
61\end{array}$ & $\begin{array}{r}5.8 \\
23.3 \\
70.9\end{array}$ \\
\hline$p$ & \multicolumn{4}{|c|}{.049} \\
\hline $\begin{array}{l}\text { Marital Status } \\
\text { Single } \\
\text { Married }\end{array}$ & $\begin{array}{r}218 \\
1\end{array}$ & $\begin{array}{r}99.5 \\
0.5\end{array}$ & $\begin{array}{r}85 \\
1\end{array}$ & $\begin{array}{r}98.8 \\
1.2\end{array}$ \\
\hline$p$ & \multicolumn{4}{|r|}{0.112} \\
\hline $\begin{array}{l}\text { Number of Siblings } \\
\text { Zero } \\
\text { One } \\
\text { Two } \\
\text { Three } \\
\text { Four and over }\end{array}$ & $\begin{array}{r}4 \\
51 \\
73 \\
48 \\
43\end{array}$ & $\begin{array}{r}1.8 \\
23.3 \\
33.3 \\
22.0 \\
19.6\end{array}$ & $\begin{array}{r}6 \\
14 \\
20 \\
25 \\
21\end{array}$ & $\begin{array}{r}7.0 \\
16.3 \\
23.3 \\
29.1 \\
24.3\end{array}$ \\
\hline$p$ & \multicolumn{4}{|c|}{.210} \\
\hline $\begin{array}{l}\text { Mother Education } \\
\text { Not literate } \\
\text { Literate } \\
\text { Primary education } \\
\text { High school } \\
\text { University } \\
\text { p }\end{array}$ & $\begin{array}{r}13 \\
20 \\
156 \\
26 \\
4\end{array}$ & $\begin{array}{r}5.9 \\
9.1 \\
71.3 \\
11.9 \\
1.8\end{array}$ & $\begin{array}{r}5 \\
6 \\
60 \\
14 \\
1\end{array}$ & $\begin{array}{r}5.8 \\
7.0 \\
69.8 \\
16.2 \\
1.2\end{array}$ \\
\hline $\begin{array}{l}\text { Father Education } \\
\text { Not literate } \\
\text { Literate } \\
\text { Primary education } \\
\text { High school } \\
\text { University }\end{array}$ & $\begin{array}{r}1 \\
9 \\
107 \\
65 \\
37\end{array}$ & $\begin{array}{r}0.5 \\
4.1 \\
48.9 \\
29.6 \\
16.9\end{array}$ & $\begin{array}{r}- \\
5 \\
51 \\
22 \\
8\end{array}$ & \begin{tabular}{r}
\multicolumn{1}{c}{} \\
5.8 \\
59.3 \\
25.6 \\
9.3
\end{tabular} \\
\hline$p$ & \multicolumn{4}{|c|}{.047} \\
\hline
\end{tabular}


Table 1: Cont.

\begin{tabular}{|c|c|c|c|c|}
\hline \multirow[t]{3}{*}{ Descriptive Characteristics } & \multicolumn{4}{|c|}{ Groups } \\
\hline & \multicolumn{2}{|c|}{ Nursing Students ( $\mathrm{n}=\mathbf{2 1 9}$ ) } & \multicolumn{2}{|c|}{ Midwifery Students $(n=86)$} \\
\hline & $\mathbf{n}$ & $\%$ & $\mathbf{n}$ & $\%$ \\
\hline $\begin{array}{l}\text { Family Structure } \\
\text { Authoritarian } \\
\text { Democratic } \\
\text { Irrelevant } \\
\text { Extremely relevant } \\
\text { Protector }\end{array}$ & $\begin{array}{r}27 \\
86 \\
4 \\
18 \\
84\end{array}$ & $\begin{array}{r}12.3 \\
39.3 \\
1.8 \\
8.2 \\
38.4\end{array}$ & $\begin{array}{r}12 \\
30 \\
5 \\
9 \\
30\end{array}$ & $\begin{array}{r}13.9 \\
34.9 \\
5.8 \\
10.5 \\
34.9\end{array}$ \\
\hline$p$ & \multicolumn{4}{|c|}{.888} \\
\hline $\begin{array}{l}\text { Income Status } \\
\text { Low } \\
\text { Middle } \\
\text { High }\end{array}$ & $\begin{array}{r}15 \\
194 \\
10\end{array}$ & $\begin{array}{r}6.8 \\
88.6 \\
4.6\end{array}$ & $\begin{array}{r}10 \\
75 \\
1\end{array}$ & $\begin{array}{r}11.6 \\
87.2 \\
1.2\end{array}$ \\
\hline $\begin{array}{l}\text { Place of Residence } \\
\text { Dormitory } \\
\text { Private dormitory } \\
\text { Home with classmates } \\
\text { With family } \\
\text { Alone } \\
\text { Home with friends }\end{array}$ & $\begin{array}{r}113 \\
36 \\
15 \\
40 \\
4 \\
11\end{array}$ & $\begin{array}{r}51.6 \\
16.4 \\
6.8 \\
18.3 \\
1.8 \\
5.1\end{array}$ & $\begin{array}{r}52 \\
20 \\
5 \\
7 \\
1 \\
1\end{array}$ & $\begin{array}{r}60.5 \\
23.3 \\
5.7 \\
8.1 \\
1.2 \\
1.2\end{array}$ \\
\hline$p$ & \multicolumn{4}{|c|}{.030} \\
\hline $\begin{array}{l}\text { Reason for Department Preference } \\
\text { Having a job } \\
\text { Family request } \\
\text { Feeling close to occupation }\end{array}$ & $\begin{array}{r}118 \\
29 \\
72\end{array}$ & $\begin{array}{l}53.9 \\
13.2 \\
32.9\end{array}$ & $\begin{array}{l}38 \\
10 \\
38\end{array}$ & $\begin{array}{l}44.2 \\
11.6 \\
44.2\end{array}$ \\
\hline$p$ & \multicolumn{4}{|c|}{.049} \\
\hline $\begin{array}{l}\text { Source of Income } \\
\text { Family } \\
\text { Learning Loan } \\
\text { Part time job } \\
\text { Salary } \\
\text { Learning Loan +partime job } \\
\text { Family+ Learning Loan }\end{array}$ & $\begin{array}{r}56 \\
130 \\
5 \\
7 \\
2 \\
19\end{array}$ & $\begin{array}{r}25.6 \\
59.4 \\
2.2 \\
3.2 \\
0.9 \\
8.7\end{array}$ & $\begin{array}{r}16 \\
57 \\
3 \\
1 \\
2 \\
7\end{array}$ & $\begin{array}{r}18.6 \\
66.3 \\
3.5 \\
1.2 \\
2.3 \\
8.1\end{array}$ \\
\hline$p$ & \multicolumn{4}{|c|}{.245} \\
\hline $\begin{array}{l}\text { Friends Group } \\
\text { There is } \\
\text { No }\end{array}$ & $\begin{array}{r}203 \\
16\end{array}$ & $\begin{array}{r}92.7 \\
7.3\end{array}$ & $\begin{array}{r}79 \\
7\end{array}$ & $\begin{array}{r}91.9 \\
8.1\end{array}$ \\
\hline$p$ & \multicolumn{4}{|c|}{.902} \\
\hline
\end{tabular}

difference between PCS total score, physical and emotional help subscales was significant $(p<.05)$. Nursing students who had a group of friends had higher scores than the total and subscales of PCS, and the difference was significant for the PCS total and physical assistance subscale $(p<.05)$. It was determined that those who had a friend group among midwifery students got higher scores than the total and all sub-dimensions of PCS and the difference was significant for the emotional assistance subdimension of PCS ( $p<0.05)$.

There was no significance between gender, graduated school, number of siblings, mother and father education, income status, place of residence and meeting financial needs, and the total score and all sub-dimensions of PCS ( $p>.05)$.

\section{Problem Solving Inventory}

When the scores of the nursing and midwifery students from the PSI sub-dimensions and total are examined, the difference between the approach / avoidance sub-dimension and the scale total scores of the nursing and midwifery students is significant $(p<.05$, Table 2$)$. When the PSI scores of the students were compared, midwifery students have a higher average PSI (Table 2). When the PSI subscale and total mean scores in nursing department were compared by gender, it was 
Table 2: Total Scores of Scales and Subgroups

\begin{tabular}{|c|c|c|}
\hline \multirow[b]{3}{*}{ Scales } & \multicolumn{2}{|c|}{ Groups } \\
\hline & Nursing & Midwifery \\
\hline & $(X \pm S D)$ & $(X \pm S D)$ \\
\hline Physical Aid & $24.29 \pm 6.65$ & $27.04 \pm 5.38$ \\
\hline$p$ & \multicolumn{2}{|c|}{.001} \\
\hline Academic Aid & $10.01 \pm 3.68$ & $11.71 \pm 2.91$ \\
\hline$p$ & \multicolumn{2}{|c|}{.000} \\
\hline Emotional Help & $10.04 \pm 3.20$ & $11.63 \pm 2.90$ \\
\hline$p$ & \multicolumn{2}{|c|}{.000} \\
\hline Peer Support Total & $44.35 \pm 12.17$ & $50.38 \pm 10.03$ \\
\hline$p$ & \multicolumn{2}{|c|}{.000} \\
\hline $\begin{array}{l}\text { Problem Solving } \\
\text { Confidence }\end{array}$ & $28.03 \pm 8.88$ & $29.20 \pm 9.13$ \\
\hline$p$ & \multicolumn{2}{|c|}{.288} \\
\hline \multirow[t]{2}{*}{ Approach-Avoidance } & $44.12 \pm 10.79$ & $47.52 \pm 10.27$ \\
\hline & \multicolumn{2}{|c|}{.005} \\
\hline Personal Control & $20.10 \pm 3.40$ & $20.53 \pm 3.92$ \\
\hline$p$ & \multicolumn{2}{|c|}{.383} \\
\hline $\begin{array}{l}\text { Problem Solving Total } \\
\text { Score }\end{array}$ & $92.21 \pm 19.52$ & $97.25 \pm 19.74$ \\
\hline$p$ & \multicolumn{2}{|c|}{.036} \\
\hline
\end{tabular}

determined that male students perceived themselves as more inadequate in problem solving than female students, and the difference between the approach / avoidance subscale and PSI total score was significant $(p<.05$, Table 4$)$. Since there are no male students in the midwifery department, the difference between the genders could not be examined.

When the school they graduated from was examined, it was determined that nursing students who had an associate degree perceived themselves as insufficient in problem solving when compared with other groups, and that the difference was significant for the approach / avoidance sub-dimension and PSI total score $(p<.05)$. In midwifery students, normal high school and bachelor's students perceived themselves to be more inadequate in problem solving compared to other groups, and the difference is significant for the problem solving confidence sub-dimension $(p<.05)$.

Nursing third classes students perceived themselves as inadequate in problem solving and the difference between them was significant for the personal control and approachavoidance sub-dimensions and total PSI $(p<.05)$. There was no difference between the classes in the midwifery students and the PSI sub-dimension and total scores ( $p>$.05). It was found that the nursing students who were not satisfied with the department had higher scores than the PSI total score and all sub-dimensions (perceived themselves to be more inadequate), and the difference was significant except for the PSI's personal control sub-dimension $(p<.05)$. It was found that midwifery students had higher scores than PSI total score and all sub-dimensions of the students who were not satisfied with the department, and the difference was significant except for the problem solving confidence of PSI only $(p<.05)$.

It has been determined that nursing students with authoritarian and irrelevant family structure perceive themselves inadequate in problem solving ( $p>.05)$. Midwifery students with irrelevant family structure scored higher than the total and all subdimensions of PSI (perceived themselves inadequate), and the difference in PSI total and personal control sub-dimensions was significant $(p<.05)$. The problem solving scores of the students who prefer the midwifery and nursing department because their family want them are higher. For midwifery students, the difference in PSI Approach-Avoidance sub-dimension is significant $(p<.05$, Table 4$)$.

\section{Peer Cooperation Scale- Problem Solving Inventory}

The relationship between nursing students' PCS and PSI total scores is not significant $(p>0.05)$. There was a very weak negative correlation between PCS physical assistance and PSI total and approach / avoidance sub-dimension score averages $(p<.05, r=-0.146)$. There was a very weak negative correlation between PCS emotional help and PSI personal control subscale scores averages ( $p<.05, r=-.149)$. In the midwifery students, there was a very weak negative correlation between PCS total, physical and academic aid subscales and PSI total and approach / avoidance scores averages ( $<.05$, Table 5).

\section{DISCUSSION}

In the study, the mean score of PSI of the student nurses was $92.21 \pm 19.52$ and the midwifery students were $97.25 \pm 19.74$. Similarly, in the study of Karadağ et al., the mean PSI total score was reported as $94.65 \pm 14.36$ for nursing students and 96.39 \pm 15.90 for midwifery (Karadağ et al., 2018). Considering that the score range to be obtained from the PSI total is 32-192, it was determined that the problem solving skills of the students were at a moderate. In previous studies, it was reported that the problem solving skills of students were at a medium level (Karadağ et al., 2018; Yıldırım, Özkahraman, \& Sarıkaya, 2014; Yılmaz, Karaca, \& Yılmaz, 2009; Yüksel, 2015). In the study and the Karadağ et al., study, it was observed that nursing students felt more competent in problem solving (Karadağ et al., 2018). The reason for these results may be that nursing students do internships in a wider variety of clinical practice areas compared to midwifery students, and the variety of cases encountered. Yıldırım et al. reported that there is no difference in problem solving skills between departments in their studies (Yıldırım et al., 2014).

People show an approach / avoidance reaction to situations or behaviors that contain emotions about themselves and others. In the approach-avoidance dimension related to problem solving skills, people define themselves more positively as the person who goes over the problem and solves it. In the study, it was observed that male students got significantly higher scores in PSI total and approach-avoidance sub-dimensions than female students. The previous study findings are also similar 


\begin{tabular}{|c|c|c|c|c|c|c|c|c|}
\hline & 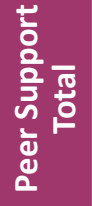 & 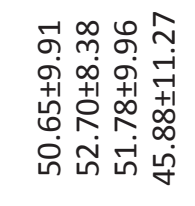 & 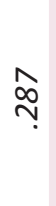 & 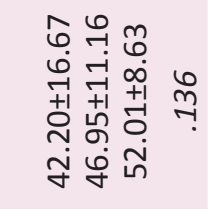 & 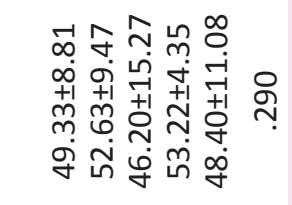 & 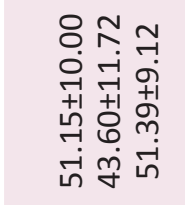 & $\underset{\overbrace{}}{\stackrel{\Im}{*}}$ & 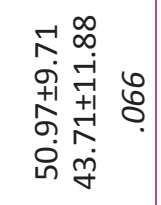 \\
\hline$\stackrel{\Xi}{=}$ & 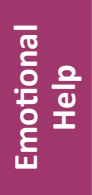 & 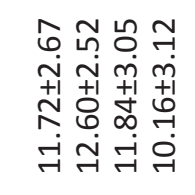 & $\frac{n}{0}$ & 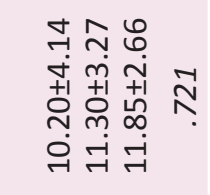 & 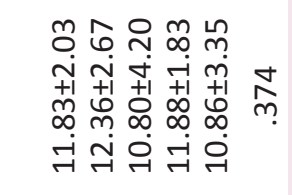 & 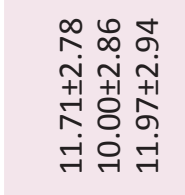 & $\stackrel{\llcorner}{m}$ & 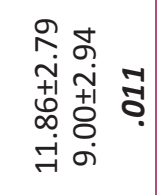 \\
\hline $\bar{\Sigma}$ & 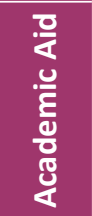 & 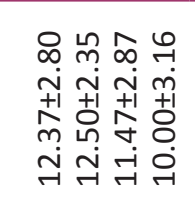 & \& & 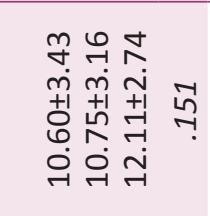 & 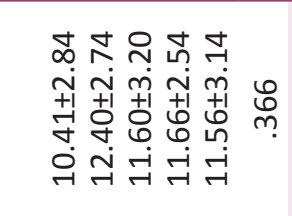 & 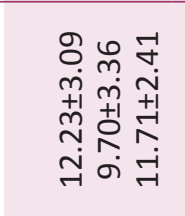 & $\ddot{\emptyset}$ & 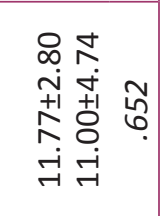 \\
\hline & 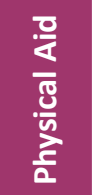 & 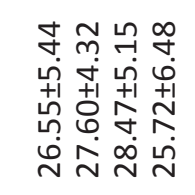 & $\widehat{\widehat{\sigma}}$ & 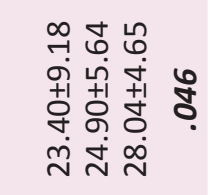 & 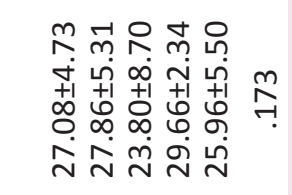 & 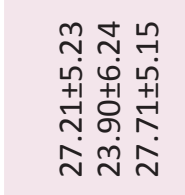 & $\underset{\overbrace{}}{\overparen{r}}$ & 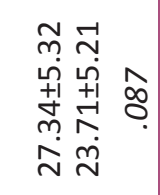 \\
\hline & 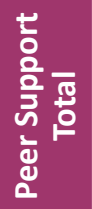 & 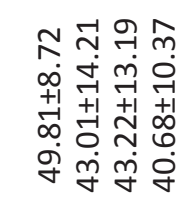 & §̣ & 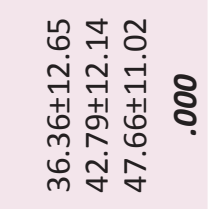 & 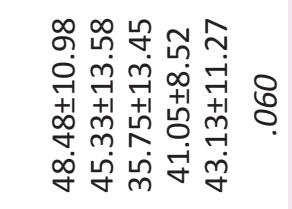 & 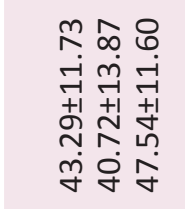 & & 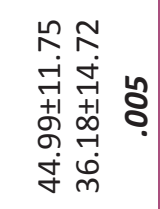 \\
\hline 20 & 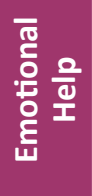 & 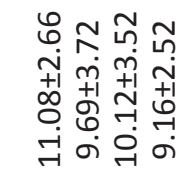 & : & 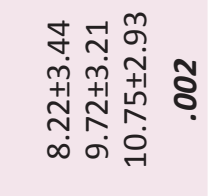 & 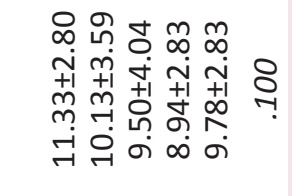 & 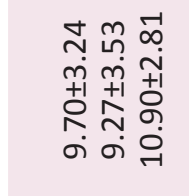 & సี & 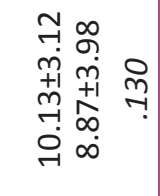 \\
\hline$\frac{5}{2}$ & 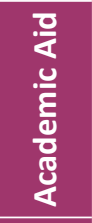 & 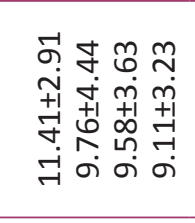 & ธุ & 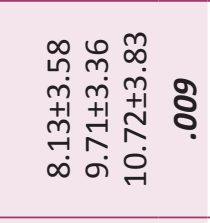 & 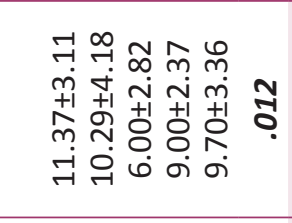 & 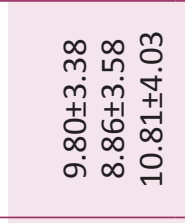 & & 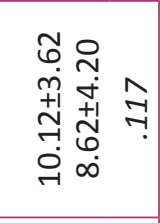 \\
\hline & $\frac{\frac{0}{4}}{\frac{0}{0}}$ & 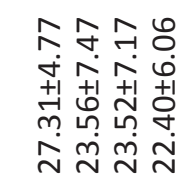 & §̣ & 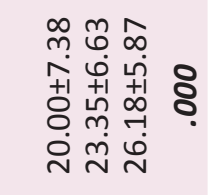 & 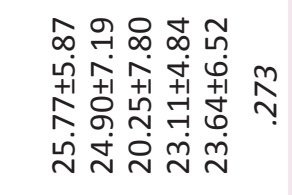 & 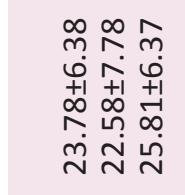 & \& & 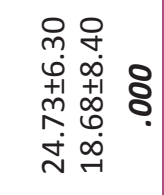 \\
\hline 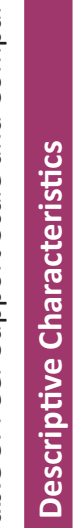 & & 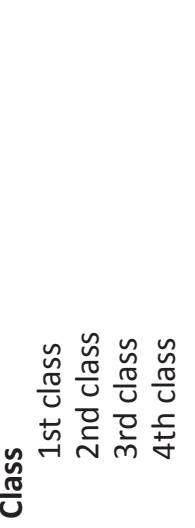 & & 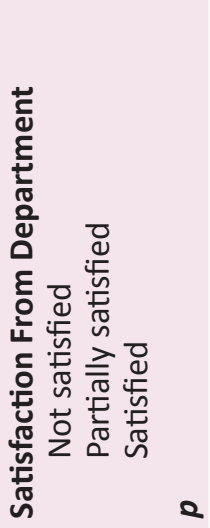 & 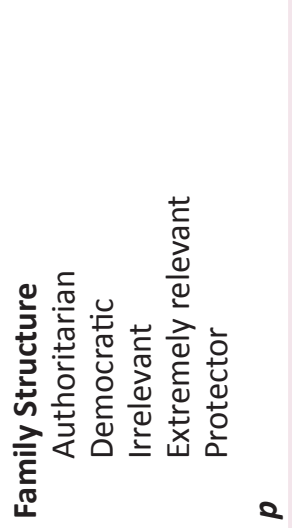 & 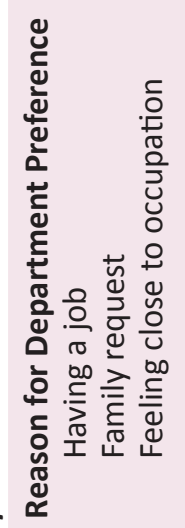 & & 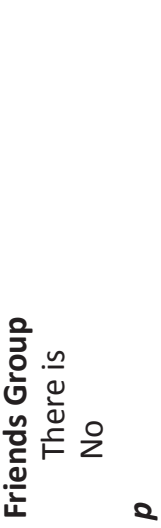 \\
\hline
\end{tabular}




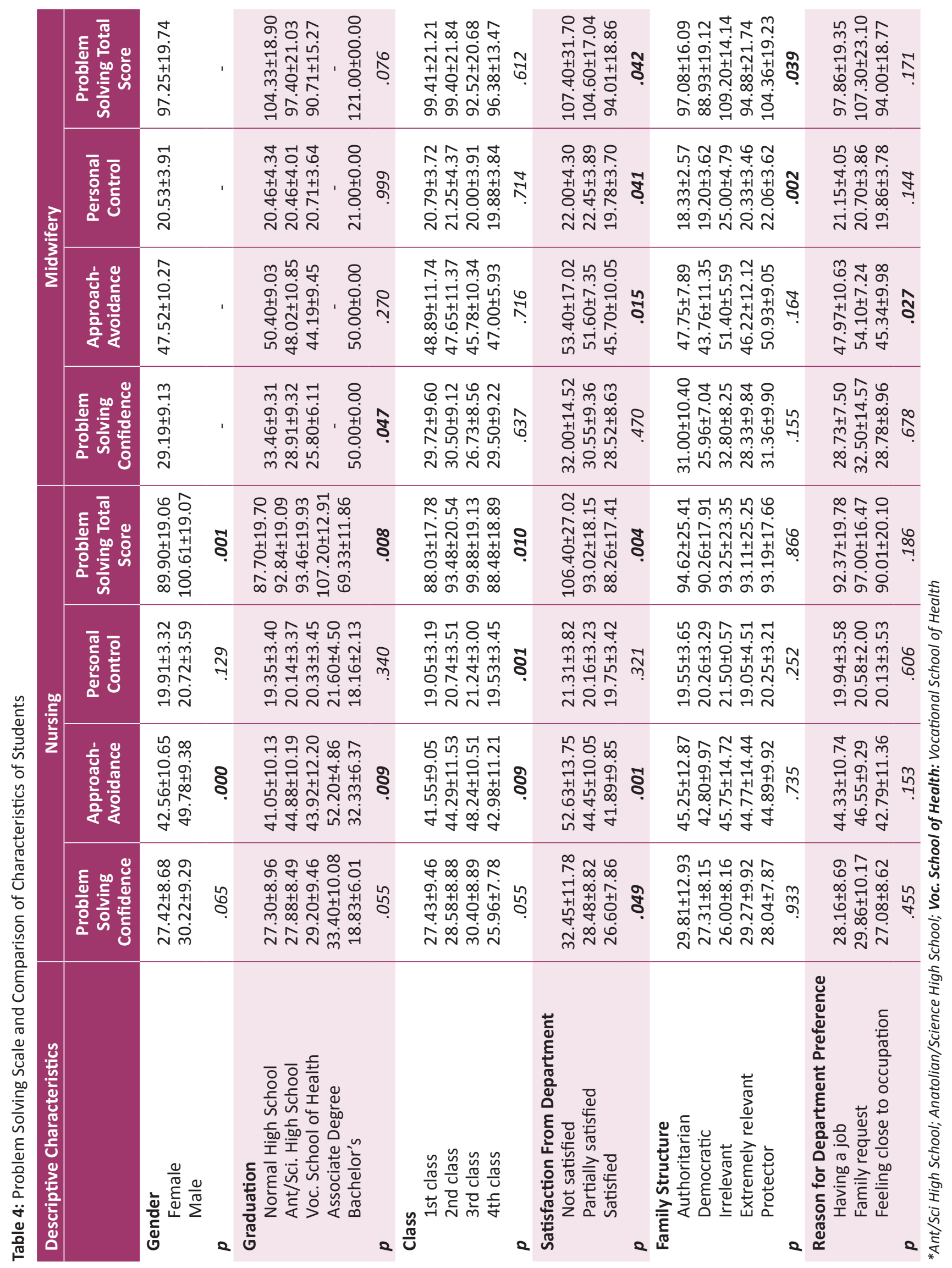




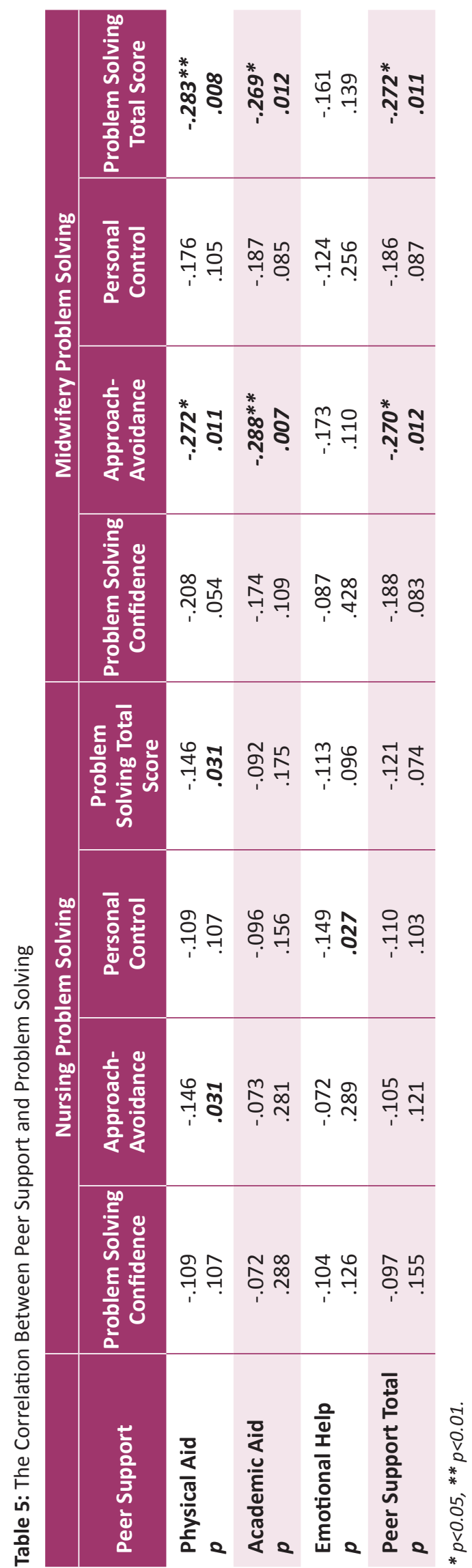

to the study findings (Korkut, 2002; Yüksel, Arıbaş, \& Bahadır, 2020). Contrary to the findings of the study, there are studies reporting that there is no difference in problem solving skills between the genders (Karadağ et al., 2018; Tümkaya, Aybek, \& Aldağ, 2009; Yıldırım et al., 2014; Yüksel, 2015). The reason why female students perceive themselves more competently in problem solving and their positive approach to emotions; It may be due to the fact that women express their feelings more easily than men.

For midwifery students who graduation health vocational high school, and nursing students who graduation bachelor's; it was determined that they perceived themselves as competent significantly in the PSI total, problem-solving confidence, and approach-avoidance sub-dimension. Contrary to the study, previous studies reported that the high school they graduated from did not affect the problem solving skills of students (Korkut, 2002; Yıldırım et al., 2014; Yüksel, 2015; Yüksel et al., 2020). The fact that undergraduate students took many courses in a higher education program and were in social environments, and those who graduated from the health vocational high school, their experience in hospital clinical practices may be the reason why they perceive themselves as sufficient in problem solving.

While first and fourth year nursing students consider themselves competent in problem solving, it has been found that third grade students consider themselves inadequate. In the midwifery department, except for the PSI personal control sub-dimension, third-grade students found themselves more adequate. The results were significant for the nursing students, but not for the midwifery students. When previous studies are examined, there are studies reporting that the classroom makes a significant difference in problem solving skills (Günüşen \& Üstün, 2011; Tümkaya et al., 2009) as well as studies showing that there is no difference (Yüksel, 2015; Yüksel et al., 2020). Unlike our study, it was reported in previous studies that problem solving skill increased from the first grade to the fourth grade (Beşer \& Kıssal, 2009). In the study of Yurttaş and Yetkin (2003), it was stated that the problem solving skills of the first graders were higher than the fourth graders. Studies have shown that there are very different results between classroom and problem solving skills. This may suggest that the classroom should not be considered as an effective factor in problem solving skill alone, individual differences and other demographic data should be taken into account.

In both departments, students who have a democratic family structure perceive themselves as more competent in problem solving. While the result was meaningful for midwifery students, it was not nursing students. While there are studies reporting that family relationships have an effect on problemsolving skills (Yüksel et al., 2020), there are some that report that family structure does not affect problem-solving skills (Yılmaz et al., 2009; Yüksel, 2015). Allowing students who grow up in a democratic family to express themselves within the family, to make decisions about themselves, and to solve problems encountered from childhood by easily talking and consulting with parents may be the reason why they perceive themselves more adequately in problem solving. 
When all subscales and total scores of PCS were compared, the difference between midwifery and nursing students was significant. Similar to the results of the study, a significant difference was found between the peer support scores of midwifery and nursing students in Atasoy and Doğu's study (Atasoy, \& Doğu, 2017). The low number of students in the midwifery department classes (20-person classes) and the same gender of the population may explain the high peer support scores of midwifery students. In the study of Çalışkan and Çınar (Çalışkan \& Çınar, 2010), there was no difference between midwifery and nursing students' PCS scores. In other studies conducted with health school students, it was reported that peer support did not make any difference between departments (Keskin \& Sezgin, 2009; Yılmaz et al., 2009).

There was no significant difference both sections students in between gender, previous school, number of siblings, mother and father education, income status, place of residence and financial needs and total score and all sub-dimensions of PCS. Although the difference in our study is health professions, it is thought that two different departments are included in the research and that the students are not only different from each other but also differentiated by characteristics such as learning areas, clinical application areas, class hours and gender distributions. Similar to this study, there was no difference between the descriptive characteristics such as gender, place of residence, and PCS subscale and total scores in previous studies (Chen, 2005; Çalışkan \& Çınar, 2010). Şimşek's (2012) study reported that female students' peer support scores were higher than male students.

Thanks to the peer group, nursing and midwifery students who have the power to interact can be used to overcome the problems related to orientation in theoretical courses and clinical practice, to facilitate their learning, and to resolve conflicts that they cannot resolve individually or between groups (Çalışkan \&Çınar, 2010). Nursing and midwifery students who have a friend group have higher PCS scores. Similar results were reached in the study conducted by Çalışkan and Çınar (Çalışkan \& Çınar, 2010). In another study, students who described their social relationships as good / very good got high scores on PCS total and sub-dimensions (Fışkın \& Doğan, 2020).

In Turkey, in a survey of 5829 university students, university students and they live in the most emotional problems indicate that these problems get help from the most friends (Çalışkan \& Çınar, 2012). In this study supporting the literature, the PCS scores of the nursing and midwifery students, who are the peer group, are higher, and the difference is significant for the emotional assistance sub-dimension. In the study of Çırpan and Çınar, contrary to our findings, it is thought that students have the opportunity to help each other more physically because they are in the field of application and they support each other less emotionally (Çırpan \& Çınar, 2013).

It has been reported that social activities and being in relationships affect students' problem solving skills (Yüksel et al., 2020). It has been reported that peer support can be used to increase the problem solving skills of students in health sciences, academic achievement, and adaptation to theoretical and applied courses (Yelten, Tanriverdi, Gider, \& Yılmaz, 2018). Nursing students in the study, there is a negative correlation between PCS physical assistance and PSI total and approach / avoidance sub-dimensions, PCS emotional assistance and PSI personal control sub-dimensions. Midwifery department students, a negative correlation was found between PCS total, physical and academic assistance sub-dimensions and PSI total approach / avoidance sub-dimensions. It is observed that there is a relationship between physical and emotional support given by students' peers and problem solving skills, understanding emotions, and their belief that they can control one's emotions and behaviors while solving problems. Nursing and midwifery students need to improve their problem-solving skills in order to adapt and cope easily against many events that they may encounter during university period and when they start their business life as health professionals in the future. It is thought that their peers have an important contribution to the development of this skill in students. For this reason, the participation of nursing and midwifery students in social and scientific activities should be supported as much as possible, they should be encouraged to take part in student clubs and societies at universities, and nurse and midwife academics are recommended to provide counseling to students on this issue.

\section{CONCLUSIONS and RECOMMENDATIONS}

As a result, it was determined that the peer support and problem solving skills of nursing and midwifery students were at medium level. Problem solving skills are higher in the nursing department and peer support in midwifery. It was determined that educational variables such as department, class, satisfaction with the department, reason for department preference, that demographic variables such as family structure affect peer support and problem solving skills. There was a relationship between peer support and problem solving. Considering that students' critical thinking dispositions are moderate, problem solving skills courses can be a useful strategy. Thus, the peer support of midwifery and nursing students as health professionals of the future will be developed and solution-oriented approaches to problems they may encounter in the clinical setting will be provided. Since there are different results in the literature on problem solving and limited studies on peer support, more comprehensive studies on the subject may be recommended.

\section{Implications for Practice}

The rapid development of technology with industrialization has left individuals facing new and increasing problems. The individual who has to solve personal, social, health and work problems will increase his / her self-confidence and his / her confidence that he / she can solve the problems that may develop. Midwifery and nursing students, the health professionals of the future, may also face many problems in the clinic during their education and in the future. Peer support is a requirement that an individual needs in every moment and year of life. Peer support can be an important factor in solving life and professional problems more effectively. 


\section{Implications for Research}

Although there are many studies related to problem solving of both nursing and midwifery students, no study has been found to evaluate problem solving and peer support. This study is thought to contribute to the field in this sense. When it is thought that midwifery and nursing students, who are health professionals of the future, will face many problems in the clinic, they have the ability to cope with this and it is concluded that peer support is important in this process.

\section{Limitations of the Study}

Since the research was conducted in a health sciences faculty, its results cannot be generalized to all nursing and midwifery students. The fact that the number of male students is lower than that of female students and the number of midwifery students compared to nursing students is a limitation of the study.

\section{REFERENCES}

Atasoy, İ., \& Doğu, Ö. (2017). Peer support importance in the school of health science students. Journal of Human Rhythm, 3(1), https://dergipark.org.tr/en/pub/johr/issue/28442/307990

Beşer, A., \& Kıssal, A. (2009). Critical thinking dispositions and problem solving skills among nursing students. E-Journal of Dokuz Eylul University Nursing Faculty, 2(3), 88-94. http:// acikerisim.deu.edu.tr/xmlui/handle/20.500.12397/4526

Carey, M.C., Kent, B., \& Latour, J.M. (2018). Experiences of undergraduate nursing students in peer assisted learning in clinical practice: a qualitative systematic review. JBI Database System Rev Implement Rep,16(5),1190-219. https://www.ncbi. nlm.nih.gov/pubmed/29762313

Chen, J.J. (2005). Relation of academic support from parents, teachers, and peers to Hong Kong adolescents' academic achievement: The mediating role of academic engagement. Genet Soc Gen Psychol Monogr, 131(2), 77-127. https://www. ncbi.nlm.nih.gov/pubmed/16779945

Çalışkan, T., \& Çınar, S. (2010). Peer cooperation: evaluation of the manners of students' working together in the classroom area and practice areas. Journal of Maltepe University Nursing Science and Art Review, Symposium Special Issue, 226-233.

Çalışkan, T., \& Çınar, S. (2012). Peer cooperation: the study of validity and reability. Marmara University Health Sciences Institute Journal, 2(1), 1-7. https://dergipark.org.tr/tr/pub/ marusbed/issue/17850/187233

Çelik, B., Karadağ, A., \& Hisar, B. (2011). Instrument of prefessional attitude for student nurses (IPASN): A confirmatory factor analytic study. Nurse Educ Today, 30, 497-500. https://doi. org/10.1016/j.nedt.2011.06.008

Çırpan, F.K., \& Çınar, S. (2013). Assessment of the relationship between peer support and academic success among students of vocational school of healthcare services. MÜSBED, 3(4), 19199. https://dergipark.org.tr/en/download/article-file/165362

Fışkın, G., \& Doğan, N. (2020). Assessment of ınterpersonal relationship and peer support in nursing and midwifery students. Pam Med J, 13, 723-732. doi:https://dx.doi. org/10.31362/patd.730211
Francis R. (Ed.) Report of the Mid Staffordshire NHS Foundation Trust Public Inquiry. Her Majesty's Stationery Office, London. 2013, ISBN: 9780102981476.

Ghadirian, F., Salsali, M., \& Cheraghi, M.A. (2014). Nursing professionalism: An evolutionary concept analysis. Iran J Nurs Midwifery Res, 19(1), 1-10. PMC3917177 https://www.ncbi. nlm.nih.gov/pmc/articles/PMC3917177/

Günüşen, N.P, \& Üstün, B. (2011). The relationship between problem solving skills levels and locus of control in nursing students. E-Journal of Dokuz Eylul University Nursing Faculty, 4(2),72-7. https://acikerisim.deu.edu.tr/xmlui/ handle/20.500.12397/4587

Heppner, P.P, \& Petersen, C.H. (1982). The development and implications of a personal problem solving inventory. J Couns Psychol, 29(1), 66-75.

Hisar, F., Karadağ, A., \& Kan, A. (2010). Development of an instrument to measure Professional attitudes in nursing students in Turkey. Nurse Educ Today, 30(8), 726-730. https:// www.ncbi.nlm.nih.gov/pubmed/20378213

Karadağ, M., Alpaslan, Ö., Yıldırım Şişman, N., \& Pekin İşeri, Ö. (2018). Problem solving skills and epistemological beliefs of nursing and midwifery students. Cukurova Medical Journal, 43, 1-6 https://dergipark.org.tr/en/pub/cumj/ issue/28626/340081

Karantzas, G.C., Avery, M.R., Macfarlane, S., Mussap, A., Tooley, G., Hazelwood, Z. et al. (2013). Enhancing critical analysis and problem-solving skills in undergraduate psychology: an evaluation of a collaborative learning and problembased learning approach. Aust J Psychol, 65 (1), 38-45. https://doi. org/10.1111/ajpy.12009

Keskin, G., \& Sezgin, B. (2009). Determining the factors that influence the status of academic success in a group of adults. Firat Journal of Health Services, 4(10), 3-18.

Korkut, F. (2002). High school students' assessment of problem solving skills in terms of some variables. Hacettepe University Journal of Education, 23, 177-84.

Kuo, C.L., Turton, M.A., Hsieh, J.L., Tseng, H.F., Hsu, C.L. (2007). Measuring peer caring behaviors of nursing students: Scae development. Int J Nurs Stud, 44, 105-14. https://www. sciencedirect.com/science/article/pii/S0020748906002562

Şahin, N.H., Şahin, N., \& Heppner, P. (1993). Psychometric properties of the problem solving inventory in a group of Turkish university students. Cognit Ther Res, 17(3), 379-85. https://link.springer.com/article/10.1007/BF01177661

Şimşek, D. (2012). Analysis of Peer Relations, Social Support Perceptions and Life Satisfaction of Primary Eighth Grade Primary School Students with Resident Primary School District and Family Members. C.U. Social Sciences Institute, Master Thesis, Adana, Turkey.

Tümkaya, S., Aybek, B., \& Aldağ, H. (2009). An investigation of university students' critical thinking disposition and perceived problem solving skills. Eurasian Journal of Educational Research, 36, 57-74.

Ünver, V., \& Akbayrak, N. (2013) Peer tutoring model in nursing education. E-Journal of Dokuz Eylul University Nursing Faculty,, $6(4), 214-217$. 
Yava, A., \& Çiçek, H. (2016). A new approach ın nursing education: Peer coaching. Journal of Hacettepe University Faculty of Nursing, 65-71.

Yelten, G., Tanrıverdi, S., Gider, B., \& Yılmaz, M. (2018). Evaluation of peer support and perceived social self-efficacy in university students, Balıkesir Health Sciences Journal, 7(1), 1-8. doi: 10.5505/bsbd.2018.36450

Yıldırım, B., \& Özkahraman, Ş. (2011). Problem solving in nursing. Suleyman Demirel University Journal of Health Sciences, 2(3): 155-159.

Yıldırım, B., Özkahraman Ş.K., \& Sarıkaya, S.K. (2014). Investıgatıng the relationshıp between learnıng modalıty and problem solvıng skılls of nursing and mıdwifery students. Gümüşhane University Journal of Health Sciences, 3(3), 859-82.
Yılmaz, E., Karaca, F., \& Yılmaz, E. (2009). Examining the problem solving skills and some related factors of the health college students. Atatürk Univ Nurs High Sch J, 12(1), 38-48.

Yurttaş, A., \& Yetkin, A. (2003). Comparison of the problem solving abilities and empathetic abilities of the students of the school of health. Journal of Atatürk University School of Nursing, 6(1), 1-13.

Yüksel, A. (2015). Nursing students' self evaluation of problem solving skills and related factors. Journal of Hacettepe University Faculty of Nursing, 37-49. https://dergipark.org.tr/ tr/pub/hunhemsire/issue/7858/103401

Yüksel, A., Arıbaş, A., \& Bahadır Yılmaz, E. (2020). The relationship between critical thinking and problem solving skills: Case of health services students. The Journal of Social Science, 4 (7), 160-174. DOI: 10.30520/tjsosci.673816 